\title{
Junio León, nueva variedad de frijol para riego y temporal el Altiplano y la Mesa Central de México*
}

\author{
Junio León, new bean variety for irrigation and rainfed \\ for the Highlands and Central Mexico
}

\begin{abstract}
JorgeAlberto Acosta-Gallegos ${ }^{1 \S}$, Yanet Jiménez-Hernández ${ }^{1}$, Víctor Montero-Tavera ${ }^{2}$, Bertha María Sánchez García ${ }^{2}$ y Salvador Horacio Guzmán-Maldonado²

'Campo Experimental Bajío-INIFAP.Carretera Celaya-San MiguelAllende,km 6.5, Celaya, Guanajuato.C.P.38110. México.Tel.01461611 5323.Ext.200.(yajiher_1013@ yahoo.com.mx). ${ }^{2}$ Campo Experimental Bajío-INIFAP. Carretera Celaya-San Miguel Allende Celaya, km 6.5, Guanajuato. C. P. 38110. México. Tel. 01461611 5323. Ext.183. (montero.victor@inifap.gob.mx; bmsgsma@yahoo.com.mx; guzman.horacio@inifap.gob.mx). ${ }^{\S}$ Autor para correspondencia: acosta.jorge@inifap.gob.mx.
\end{abstract}

\section{Resumen}

El frijol de tipo Flor de Junio es de alta demanda en la región centro de México; es producido bajo condiciones de riego y temporal en los estados de Zacatecas, San Luis Potosí y Guanajuato, principalmente. La nueva variedad Junio León se derivó de la cruza simple de Flor de Junio Marcela por Flor de Mayo Anita realizada en 2004 en el Campo Experimental Bajío. Es de hábito indeterminado-postrado y se adapta bien en siembras a doble hilera o en hilera sencilla. El grano es de tamaño medio (34 g en 100 granos), de fondo crema y rayas rosa. Esresistente al tizón común y tizón de haloy bajo temporal presenta una incidencia menor (1.8) de roya, en comparación conFlor de Junio Marcela (4). Junio León posee los marcadores asociados a los genes $U r 6$ y $U r$, de origen Andino, genes importantes porque en combinación con los genes de origen Mesoamericano que posee $(U r 3, U r 4, U r 5$ y $G B)$, muestran un amplio espectro de resistencia a la roya. En contenido de proteína, el grano de Junio León fue superior al de Marcela en condiciones de riego y similar bajo temporal, así mismo, el tiempo de cocción resultó similar bajo ambas condiciones.

Palabra clave: Phaseolus vulgaris, frijol tipo Flor de Junio, calidad de semilla, resistencia a roya.

\section{Abstract}

Beans of Junio Flower type is in high demand in the center of Mexico region, produced under irrigation and rainfed conditions in the States of Zacatecas, San Luis Potosí and Guanajuato, mainly. The new variety Junio León was derived from the single cross Junio Flower Marcela by Flor de Mayo Anita conducted in 2004 in the Experimental Field El Bajío. Is indefinite-prostrate habit and adapts well to planting in double rows or single row. The grain size is medium ( $34 \mathrm{~g}$ in 100 grains), cream and pink striped background. It is resistant to common blight and halo blight and temporary low has a lower incidence (1.8) rust, compared to Junio Flower Marcela (4). Junio León has markers associated with $U r 6$ and $U r 9$ genes of Andean origin, because important genes in combination with genes having Mesoamerican origin ( $U r 3 U r 4 U r 5$ $G B$ ), show a wide spectrum of rust resistance. In protein content, grain Junio León was higher than Marcela under irrigation and similar under rainfed, also cooking time was similar under both conditions.

Keyword: Phaseolus vulgaris, Junio Flower type bean, seed quality, rust resistance.

\footnotetext{
* Recibido: septiembre de 2013

Aceptado: febrero de 2014
} 
El frijol tipo Flor de Junio se produce durante el ciclo primavera-verano $(\mathrm{PV})$ en las regiones del altiplano centraly semiárido (Guanajuato, San Luis Potosí y Zacatecas). En el Bajío se produce bajo riego, al final de febrero y en temporal a fines de junio a mediados de julio. En el ciclo otoñoinvierno (OI) también se produce en el estado de Nayarit bajo condiciones de riego y humedad residual. La cantidad de este tipo de frijol producida en 2010 fue de 110 mil toneladas. Sólo se han registrado dos variedades mejoradas tipo flor de junio: Flor de Junio Marcela (FJM) (Castellanos et al., 2003a) y Dalia (Acosta-Gallegos et al., 2014). FJM se desarrolló para el Bajío; sin embargo, por la alta demanda, también se produce bajo temporal en la región semiárida de Guanajuato, San Luis Potosí y Zacatecas. FJM tiene algunas desventajas como la susceptibilidad a roya y antracnosis que afectan su rendimiento en siembras atrasadas y presencia temprana de enfermedades. Dalia posee resistencia múltiple a enfermedades y amplia adaptación bajo condiciones de temporal (Acosta-Gallegos et al., 2012).

Junio León se derivó de la cruza simple de FJM(Castellanos et al., 2003a) por Flor de Mayo Anita (FMA) (Castellanos et al., 2003b) realizada en el CEBAJ en 2004. FMA posee el gen $I$, que confiere resistencia al virus del mosaico común del frijol (BCMV), y FJM posee los genes $I$ y $b c 3$ que confieren resistencia a $\mathrm{BCMVy}$ al virus necrótico del mosaico común del frijol(BCMNV), pero es susceptible a la roya. La cruza se realizó con el objetivo de recuperar líneas con grano similar al de FJM con resistencia a la roya.

El proceso de selección de Junio León se realizó en el Campo Experimental Bajío (CEBAJ) en condiciones de riego y temporal en dos generaciones alternas por año. Entre la generación temprana $\mathrm{F}_{2} \mathrm{y}$ la intermedia $\mathrm{F}_{7}$, la selección se hizo con base en la sanidad de las plantas, la carga de vainas y las características del grano. A partir de la generación $\mathrm{F}_{3}$ la selección de Junio León fue entre y dentro de familias, y en $\mathrm{F}_{10}$ se consideró fenotípicamente uniforme, porloque se incorporó con otras 34 líneas en un ensayo preliminar de rendimiento durante el ciclo PV 2009, ensayo que fue establecido en dos localidades de Guanajuato, el CEBAJ en Celayay el SENGUA en San Luis de la Paz. La genealogía de Junio León es:

(Flor de Junio Marcela/Flor de Mayo Anita)-M-6-1-4-11-MU.

La planta de Junio León es de habito indeterminado-postrado, tipo 3 (Shoonhoven y Pastor-Corrales, 1987), con abundantes guías de tamaño medio y flores blancas. Cuando se siembra
The Junio Flower type bean occurs during the springsummer (PV) cycle in and semiarid regions of the central highlands (Guanajuato, San Luis Potosí and Zacatecas). In El Bajío grown under irrigation at the end of February and the end of Junio time in mid-July. In the autumn-winter (AW) also occurs in the state of Nayarit under irrigation and residual moisture. The amount of this type of beans produced in 2010 was 110 thousand tons. There has been only two improved varieties flower type Junio: Junio Flower Marcela (FJM) (Castellanos et al., 2003a.) and Dalia (Acosta-Gallegos et al., 2014.). FJM was developed for the shoal, but by high demand, also occurs in foster in the semiarid region of Guanajuato, San Luis Potosí and Zacatecas. FJM has some disadvantages as susceptibility to rust and anthracnose affecting performance in backward crops and early presence of disease. Dalia has multiple disease resistance and wide adaptation under rainfed conditions (Acosta-Gallegos et al., 2012).

Junio León was derived from the single cross of FJM (Castellanos et al., 2003a) by Flor de Mayo Anita (FMA) (Castellanos et al., 2003b) on the CEBAJ in 2004. FMA has the I gene, which confers resistance to bean common mosaic (BCMV) virus, and FJM has $b c 3$ and $I$ genes conferring resistance to necrotic virus $\mathrm{BCMV}$ and bean common mosaic (BCMNV), but is susceptible to rust. The cross was performed with the aim of recovering lines similar to FJM rust resistant grain.

The selection process of Junio León was conducted in El Bajío Experimental Field (CEBAJ) under irrigated conditions and alternative temporal two generations per year. Among the early generation $\mathrm{F}_{2}$ and intermediate $\mathrm{F}_{7}$, the selection was based on the health of plants, charging pods and grain characteristics. From generation $\mathrm{F}_{3}$, selection of Junio León was between and within families, and $\mathrm{F}_{10}$ was phenotypically uniform, joined with other 34 lines in a preliminary yield trial during PV 2009 cycle test which was established at two locations in Guanajuato, the CEBAJ SENGUA Celaya and San Luis de la Paz. Genealogy Junio León is:

(Marcela Junio Flower/Flor de Mayo Anita)-M-6-1-4-11-MU.

The plant Junio León is indeterminate of prostrate habit, type 3 (Shoonhoven and Pastor-Corrales, 1987), media guides with abundant white flowers and size. When planted 
en suelo húmedo en febrero la emergencia ocurre a los 12 días, mientras que en el ciclo PV la emergencia toma alrededor de siete días. Es de ciclo intermedio-tardío con 55 y 110 días a la floración y madurez fisiológica, respectivamente(Cuadro 1); su planta es de mayor volumen que la de FJM y el color del follaje es verde medio. Se adapta bien a las siembras a doble hilera en surcos de 0.9 a 1.2 mdeancho o en hilera sencillaa 0.76 u 0.80 m de separación. Estos sistemas de siembra facilitan las labores de cultivo, cosechay aplicación de riegos. La madurez fisiológica ocurre tres a cinco días después que la de FJM en riego, mientras que en temporal son de fenología similar. in moist soil in February the emergency occurs at 12 days, while in the emergency PV cycle takes about seven days. Of intermediate-late cycle 55 and 110 days to flowering and physiological maturity, respectively (Table 1), its plant is the largest volume of FJM and color of the foliage is medium green. Adapts well to planting in double rows 0.9 to $1.2 \mathrm{~m}$ wide or single row to 0.76 or $0.80 \mathrm{~m}$ apart. These systems facilitate sowing tillage, harvesting and irrigation applications. Physiological maturity occurs three to five days after the irrigation of FJM while under rainfed are of similar phenology.

Cuadro 1. Características agronómicas de frijol tipo Flor de Junio sembradas en Guanajuato.

Table 1. Agronomic traits of bean flower Junio planted in Guanajuato.

\begin{tabular}{|c|c|c|c|c|c|c|}
\hline \multirow[b]{2}{*}{ Variedad } & \multicolumn{2}{|c|}{ Días a } & \multicolumn{2}{|c|}{ Reacción $^{1} \mathrm{a}$} & \multirow{2}{*}{$\begin{array}{c}\text { Rto. } \\
\text { kg ha }^{-1}\end{array}$} & \multirow{2}{*}{$\begin{array}{c}\text { P100S } \\
\text { G }\end{array}$} \\
\hline & Flor & Madurez & Tizón común & Roya & & \\
\hline & & & Riego $^{3}$ & & & \\
\hline J. León & 60 & 101 & 3.0 & 1.0 & 1990 & 33.7 \\
\hline FJM & 60 & 98 & $\begin{array}{c}4.0 \\
\text { Temporal }^{4}\end{array}$ & 1.0 & 2002 & 34.5 \\
\hline J. León & 49 & 95 & 1.6 & 1.8 & 3394 & 33.9 \\
\hline FJM & 49 & 95 & 2.4 & 4.0 & 2809 & 32.9 \\
\hline
\end{tabular}

Las vainas de Junio León son de color verde y al final del llenado de grano se tornan rosa-violeta. El grano es de tamaño medio de alrededor de $34 \mathrm{~g}$ en 100 granos, el peso varía ligeramente de acuerdo con las condiciones ambientales al final del llenado de grano; posee dos colores, fondo crema con franjas rosa, forma oval-alargada. Ocasionalmente y en respuesta al ambiente durante la maduración, por ejemplo alta insolación, el tono del color rosa del grano se intensifica ligeramente. Entre las enfermedades que afectan al frijol las bacterias causantes del tizón común, inducido por Xanthomonas campestris pv. phaseoli (xcp) y tizón de halo (Pseudomonas siyringae pv phaseolicola), se transmiten a través de la semilla o grano utilizado para la siembra (Navarrete-Maya et al., 2008). En dos de cuatro localidades establecidas durante el ciclo PV de 2010, la semilla de Junio León presentó $3.3 \mathrm{ufc} \mathrm{ml}^{-1}$ (unidades formadoras de colonias), cantidad relativamente pequeña si se compara con la obtenida en Villa de Arriaga, San Luís Potosí en semilla de la línea FMB 08058 (Cuadro 2).

En el caso de la roya, causada por el hongo Uromyces appendiculatus, el cual posee muchas razas fisiológicas y es también de patogenicidad altamente variable. Harter et al. (1935) identificaron dos razas fisiológicas de roya en 1935 y para 1996 se habían reportado más de 300 alrededor
Junio León pods are green and end of grain filling become pink-violet. The grain is medium in size from about $34 \mathrm{~g}$ to 100 grains, the weight varies slightly with the ambient at the end of grain filling conditions; has two colors, cream background with pink stripes, elongated-oval shape. Occasionally and in response to the environment during maturation, eg high insolation, the tone of pink grain intensifies slightly. Among the diseases that affect the bacteria that cause bean common blight induced by Xanthomonas campestris pv. Phaseoli (xcp) and halo blight (Pseudomonas phaseolicola pv siyringae), transmitted through the seed or grain used for planting (NavarreteMaya et al., 2008). In two of four locations established during the 2010 cycle PV, Junio León seed provided $3.3 \mathrm{cfu}$ $\mathrm{ml}^{-1}$ (colony forming units) relatively small amount when compared with that obtained in Villa de Arriaga, San Luis Potosí in seed FMB 08058 (Table 2) line.

In the case of the rust caused by the fungus Uromyces appendiculatus, which has many physiological races and is highly variable in pathogenicity. Harter et al. (1935) identified two physiological races of rust in 1935 and by 1996 had reported more than 300 around the world (Araya et al.,2006). The average incidence of rust through temporary six experiments was 4 in FJM, larger than Junio León, 1.8. 
del mundo (Araya et al., 2006). La incidencia promedio de roya a través de seis experimentos de temporal fue de 4 en FJM, mayor que la de Junio León que fue de 1.8.

En el laboratorio de marcadores moleculares del CEBAJ, se verificóla presenciademarcadores asociados conla resistencia a roya y antracnosis (Colletotrichum lindemuthianum) en 50 plantas individuales de Junio León. En el caso de roya, todas las plantas mostraron los marcadores asociados a los genes $U r$ 3, Ur 4, Ur 5, Ur 6 y $G B$ y sólo $46 \%$ de las plantas mostraron el gen $U r 9$, de origen Andino. Éste último, junto con $U r 6$ son muy importantes porque en combinación con genes de origen Mesoamericano, muestran un amplio espectro de resistencia (Singh y Schwartz, 2010); por ello, se realizó un proceso extra de selección con base en el marcador específico asociado a ese gen para uniformizar la línea. En el caso de la antracnosis Junio León presentó de manera uniforme los marcadores asociados a los genes: $\mathrm{Co} 1, \mathrm{Co} 2, \mathrm{y} \mathrm{Co}^{2}$; estos genes proporcionan a Junio León resistencia a la mayoría de las razas de antracnosis presentes en el Altiplano y la Mesa Central (González-Chavira et al., 2004).

En el caso de producción de semilla de Junio León, deberá llevarse a cabo bajo condiciones de riego, en siembras de Invierno-Primavera y proteger el cultivo para prevenir ataque de patógenos durante el ciclo y evitar la contaminación a la semilla. En el ciclo de PV 2010, se observó en el CEBAJ, Celaya, Guanajuato, alta incidencia del mildéu velloso causado por el hongo Phytoptora phaseoli, enfermedad que causa la muerte de los puntos de crecimiento. Ésta enfermedad sólo se observa en años de alta precipitación y en 2010 Junio León mostró reacción de 2 en comparación con 7 de FJM, escala de 1 a 9 (Shoonhoven y Pastor-Corrales, 1987).

La línea que dio origen a Junio León se codificó como FJB 08045, y a partir de 2009 se comenzó a evaluar en localidades de riego y temporal en Guanajuato. Las evaluaciones se realizaron entre 2009 y 2013. Además de su evaluación en ensayos de rendimiento, en 2011, 2012 y 2013 se estableció junto con otras variedades en vitrinas de validación en el CEBAJ y campos de agricultores en Durango, Zacatecas, Aguascalientes, San Luis Potosí y Guanajuato. En una parcela semicomercial de media hectárea, Junio León sembrado a doble hilera en Acámbaro, Guanajuato, en 2012 obtuvo 4.6 t ha- $^{1}$ bajo condiciones de temporal favorable.

Por otra parte, los resultados obtenidos bajo condiciones de riego en siembras de febrero en Celaya, Guanajuato, han resultado pobres por alta temperatura de $34{ }^{\circ} \mathrm{C}$ que
Cuadro 2. Presencia de la bacteria Pseudomonas syringae pv. phaseolicola en semilla de tres genotipos de frijol tipo flor de junio producida en cuatro localidades, ciclo primavera-verano, 2010.

Table 2. Presence of the bacterium Pseudomonas syringae pv. Phaseolicola seed three bean genotypes of Junio Flower type produced in four locations, springsummer cycle, 2010.

\begin{tabular}{lcccc}
\hline & \multicolumn{2}{c}{ San Luis Potosí } & \multicolumn{2}{c}{ Guanajuato } \\
\cline { 2 - 5 } Variedad & $\begin{array}{c}\text { Villa de } \\
\text { Ramos }\end{array}$ & $\begin{array}{c}\text { Villa de } \\
\text { Arriaga }\end{array}$ & $\begin{array}{c}\text { CEBAJ } \\
\text { Celaya }\end{array}$ & $\begin{array}{c}\text { Dolores } \\
\text { Hidalgo }\end{array}$ \\
\hline Junio León & 0 & 0 & $3.3^{1}$ & 3.3 \\
FJ Marcela & - & - & 0 & 3.3 \\
FJB 08058 & 3.3 & 333.3 & - & - \\
\hline '(ufc/ml: unidades formadoras de colonias de Psp por ml), media de 3 repeticiones, \\
-= no se cultivó en esa localidad.
\end{tabular}

In the laboratory molecular markers, the presence of markers associated with the resistance to rust and anthracnose (Colletotrichum lindemuthianum) on 50 Junio León individual plants was verified. For rust, all plants showed associated markers $U r 3 U r 4 U r 5,6$ and $G B U r$ genes and only $46 \%$ of the plants showed Ur 9 gene, origin Andino. The latter, along with Ur 6 are very important because in combination with genes of Mesoamerican origin, show a broad spectrum of resistance (Singh and Schwartz, 2010), therefore, an extra selection process was conducted based on the specific marker associated that gene to standardize the line. For anthracnose Junio León presented uniformly markers associated with genes: $\mathrm{Co} 1 \mathrm{Co} 2$ and $\mathrm{Co}_{4}^{2}$; these genes provide resistance to Junio León most anthracnose races present in the Altiplano and Mesa Central (González-Chavira et al., 2004).

For seed production Junio León must be conducted under irrigated conditions in Winter-Spring plantings and protect the crop to prevent pathogen attack during the cycle and prevent pollution to the seed. In the cycle of PV 2010, was observed in the CEBAJ, Celaya, Guanajuato, high incidence of downy mildew caused by the fungus Phytoptora phaseoli, a disease that causes the death of the growing points. This disease is seen only in years of high rainfall and León in 2010 Junio showed reaction of 2 compared to 7 FJM scale of 1-9 (Shoonhoven and Pastor-Corrales, 1987).

The line that gave rise to Junio León was coded FJB 08045, and from 2009 began to evaluate irrigation and temporal localities in Guanajuato. Evaluations were performed between 2009 and 2013. Besides evaluation in yield trials in 2011, 2012 and 2013 was established along with other 
causan la caída de flores y pequeñas vainas, al tiempo que se favorece una mayor presión por insectos como la mosca blanca (Trialuroides vaporariorum), chicharrita (Empoasca kraemeri) y el ácaro manchado (Tetranichus sp.) y por enfermedades virales y bacterianas.

Calidad del grano. En contenido de hierro, zinc y proteína, FJM resulto superior a Junio León bajo temporal, mientras que Junio León fue superior en contenido de proteína en riego. En grano cosechado en Celaya, Guanajuato, la capacidad de absorción de agua (CAA) fue diferente y contraria entre FJM y Junio León en riego y temporal, y el tiempo de cocción resultó similar bajo ambas condiciones (Cuadro 3). Esos valores de calidad están dentro del rango normal para frijol. El contenido de minerales y proteína es similar al reportado para el frijol (Díaz-Batalla et al., 2006).

La siembra para producción de semilla debe ser en un lote en el que no se haya sembrado frijol por dos ciclos anteriores. La multiplicación de semilla puede realizarse en la época de otoño-invierno bajo condiciones de riego en la región de El Bajío y en Sinaloa. La multiplicación de semilla debe llevarse a cabo con aislamiento mínimo de $5 \mathrm{~m}$ y realizar desmezcle de plantas fuera de tipo a partir de la floración. La semilla original de Junio León se conserva en el Programa de Frijol y Garbanzo del CEBAJ, donde también se cuenta con semilla de categoría básica para su venta a compañías productoras de semilla y organizaciones de productores. varieties in glass cases in the validation CEBAJ and farmers' fields in Durango, Zacatecas, Aguascalientes, San Luis Potosí and Guanajuato. In a semi-acre commercial plot, Junio León planted in double rows in Acambaro, Guanajuato, in 2012 obtained $4.6 \mathrm{t} \mathrm{ha}^{-1}$ under favorable conditions.

Moreover, the results obtained under irrigation in February sowings in Celaya, Guanajuato, have been poor because of high temperatures of $34{ }^{\circ} \mathrm{C}$ to cause the fall of flowers and small pods, while a higher pressure is favored by insects as whitefly (Trialuroidesvaporariorum), leafhopper(Empoascakraemeri) andspottedmite(Tetranychussp.)andviralandbacterialdiseases.

Quality grain. The content of iron, zinc and protein, FJM was superior to Junio León, with higher protein contentin irrigation. In harvested in Celaya, Guanajuato grain, water absorption capacity (FAC) was different and contrary between Junio León andFJMirrigation and rainfed, and the cooking time was similar under both conditions (Table 3 ). These quality valuesare within the normal range for beans. The content ofminerals and protein is similar to that reported for beans (Díaz-Batalla et al., 2006).

The sowing for seed production must be in a batch in which beans planted has not been two previous cycles. Seed multiplication can be done in the autumn-winter season under irrigation in the region of El Bajío and Sinaloa. Seed multiplication should be carried out with minimumisolation of 5 desmezcle that make the off-type plants fromflowering. The

Cuadro 3. Contenido de hierro, zinc (ppm), Proteína (\%), capacidad de absorción de agua (CAA); (\%) y tiempo de cocción (TC, min) del grano de dos variedades de frijol producidas bajo riego y temporal en Celaya, Guanajuato, 2012. Table 3. Content of iron, zinc (ppm), protein (\%), water absorption capacity (FAC) (\%) and cooking time (CT min) grain of two varieties of beans grown under irrigation and rainfed in Celaya, Guanajuato, 2012.

\begin{tabular}{|c|c|c|c|c|c|}
\hline \multirow[t]{2}{*}{ Variedad } & Hierro & Zinc & Proteína & CAA & $\mathrm{TC}$ \\
\hline & \multicolumn{5}{|c|}{ Riego } \\
\hline FJM & $6.0 \pm 0.19^{1}$ & $2.7 \pm 0.14$ & $17.7 \pm 0.39$ & $100 \pm 4.4$ & $132 \pm 5$ \\
\hline Junio León & $6.1 \pm 0.13$ & $2.4 \pm 0.15$ & $\begin{array}{c}21.2 \pm 0.88 \\
\text { Temporal }\end{array}$ & $94 \pm 0.0^{1}$ & $124 \pm 8$ \\
\hline FJM & $9.1 \pm 0.21$ & $3.4 \pm 0.00$ & $20.8 \pm 0.30$ & $92 \pm 2.1$ & $124 \pm 9$ \\
\hline Junio León & $6.2 \pm 0.36$ & $2.1 \pm 0.07$ & $16.4 \pm 1.67$ & $109 \pm 1.5$ & $131 \pm 9$ \\
\hline
\end{tabular}

${ }^{1}$ Promedio de tres repeticiones \pm desviación estándar.

\section{Agradecimientos}

Por el financiamiento de los proyectos: "Mejoramiento del cultivo del frijol en Guanajuato" (Fundación Guanajuato Produce, A. C. Folio FGP: 492/08, y Folio SIFP: 11-2008- original seed of JunioLeón retained in Garbanzo Bean Program and the CEBAJ, which also has basic category seed for sale to seed producing companies and producer organizations.

End of the English version 
0593); “Desarrollo de variedades de frijol dealtorendimiento, tolerantes a sequía, resistentes a patógenos y con la calidad que demanda el consumidor" (SAGARPA-2009-109621).

\section{Literatura citada}

Acosta-Gallegos, J. A.; Montero-Tavera, V.; Jiménez-Hernández, Y.; Anaya-López, J. L. y González-Chavira, M. M.2014. "Dalia", nueva variedad de frijol de grano tipo Flor de Junio para la región centro de México. Rev. Mex. Cienc.Agric. 5(2):331-336.

Araya, C. M.; Alleyne, A. T.; Steadman, J. R.; Eskridge, K. M. and Coyne. D. P. 2006. Phenotypic and genotypic characterization of Uromyces appendiculatus from Phaseolus vulgaris in the Americas. Plant Dis. 88:830-836.

Castellanos-Ramos, J.Z.; Guzmán-Maldonado, S.H.;Acosta-Gallegos, J. A. and Kelly, J. D. 2003a. Registration of Flor de Junio Marcela bean cultivar. Crop Sci. 43:1121-1122.

Castellanos-Ramos, J. Z.; Guzmán-Maldonado, S. H. Muñoz-Ramos, J. y Acosta-Gallegos, J. A. 2003b. Flor de Mayo Anita, nueva variedad de frijol para la región central de México. Rev. Fitotec. Mex. 26:209-211.
Diaz-Batalla, L.; Widholm, J. M.; Fahey, G. C. Jr.; Castaño-Tostado, E. y Paredes-López, O. 2006. Chemical components with health implications in wild and cultivated Mexican common bean seeds (Phaseolus vulgaris L.). J. Agric. Food Chem. 54:2045-2052.

González-Chavira, M.; Rodríguez-Guerra, R.; Acosta-Gallegos, J.; Martínez de la Vega, O. and Simpson, J. 2004. Analysis of pathotypes of Colletotrichum lindemuthianum found in the central region of Mexico and resistance in elite germplasm of Phaseolus vulgaris. Plant Dis. 88(2):152-156.

Harter, L. L.; Andrus, C. F. and Zaumeyer, W. J. 1935. Studies on bean rust caused by Uromyces phaseoli typica on bean. J. Agric. Res. 50:737-759.

Navarrete-Maya, R.; Acosta-Gallegos, J. A.; Ibarra, P. F. J.; Cuéllar, R. E. I. y Rosales, S. R. 2008. Bacteriosis común del frijol inducida por Xanthomonas campestris pv. phaseoli. Campo Experimental Bajío, Celaya, Guanajuato, México. Folleto técnico Núm. 10.36 p.

Shoonhoven A. van y Pastor-Correales M. P.1987. Sistema estándar para la evaluación de germoplasma de frijol. CIAT, Cali, Colombia $57 \mathrm{p}$.

Singh, S. P. and Schwartz, H. F. 2010. Breeding common bean for resistance to diseases: a review. Crop Sci. 50(6): 2199-2223. 